\title{
The Impact of the Financial Crisis on the Islamic Banks Profitability - Evidence from GCC
}

\author{
Mousa Almanaseer ${ }^{1}$ \\ ${ }^{1}$ Banking Finance, Applied Science University, Jufair, Kingdom of Bahrain \\ Correspondence: Dr. Mousa Almanaseer, Associate Professor, Banking Finance, Applied Science University, P.O. \\ Box 5055, Jufair, Kingdom of Bahrain. E-mail: mousa_almanaseer@yahoo.com
}

Received: May 20, 2014

doi:10.5430/ijfr.v5n3p176
Accepted: June 7, 2014

Online Published: June 19, 2014

URL: http://dx.doi.org/10.5430/ijfr.v5n3p176

\begin{abstract}
Using pooled data for 24 Islamic banks operating in Bahrain, Kuwait, Qatar, Saudi Arabia and UAE over the 2005-2012 period the current study examines empirically the impact of the global financial crisis on the Islamic banks' profitability.

The study finds that the financial crisis does not have significant impact on Islamic banks profitability. Favorable macro-economic conditions, bank size and equity capital are important factors in increasing Islamic banks' profitability. Furthermore Increasing owners' equity decreased the impact of financial crisis on Islamic banks profitability. On the other hand, the impact of the financial crisis on Islamic banks' profitability increase with increasing banks total assets, liquidity and overhead expenses. The study recommends increasing both Islamic banks' size and equity capital in addition to reducing their overhead expenses and liquidity in order to increase their profitability and decrease the impact of financial crisis in their performances.
\end{abstract}

Keywords: financial crisis, Islamic banks profitability, GCC (Gulf Cooperation Council)

\section{Introduction}

The 2007global crisis is recognized as a sequence of global crises since the 1970s and started with the subprime mortgage in the United States. This crisis is the most important and exceptional one among the other financial crises because of the significant impact it had not only on the US economy but also on other major economies in the world. This crisis occurs in countries with developed more than other countries. It has given a wide array of impacts to the operating and financial performance of many banks all over the world (Ellaboudy, 2010; Smolo and Mirakhor, 2010; Kassim and Majid, 2010). As a result, many banks across the world reported financial losses on their financial reports due to their connections with subprime mortgage in the U.S. or were simply affected by economic recession in their own countries. The impact of the crisis have even forced around 123 banks in the U.S. to file for bankruptcy in the year, including American giant bank Lehman Brother that was never been expected to fail.

Examining the impact of financial crisis on banks' profitability is an important issue, especially as the recent global financial crisis affected significantly banks and financial institutions worldwide, mainly their profitability. For example, customers are interested in knowing the prices and the quality of the services provided by banks. These are strongly influenced by the bank's overall profitability. Furthermore, an awareness of profitability features helps policy makers to formulate effective policies and regulations for the banking industry. There have been many studies examining the consequences of the global financial crisis 2007 on the conventional banking sector of different countries (see for example, Anayiotos et al. 2010; Dietrich and Wanzenried 2011; Sufian 2010 and Perlich 2009). The results of these studies show that the profitability of the financial institutions has been significantly impacted by this crisis. However, despite the relevant coverage of literature toward the impact of the financial crisis on conventional banks profitability, limited research work is undertaken to examine the impact of this crisis on Islamic banks' profitability in GCC (Gulf Cooperation Council) countries. Thus, the current study is expected to fill this gap in the literature.

\subsection{The Study Objectives}

The purpose of this study is to investigate the impact of the global financial crisis on Islamic banks' profitability. More precisely, the study seeks to: (i) examine, the impact of this crisis on Islamic banks' profitability across the GCC countries; (ii) examine, whether the impact of this crisis vary with variation on each internal determinant of Islamic banks' profitability separately across the GCC countries. 


\subsection{Method}

Previous studies have considered several functional forms for examining the determinants of bank profitability. However, these studies have concluded that the linear model produces results that are as good as any other functional form (see Bourke (1989); Ben-naceur and Goaied (2008); Khrawish, Al-Abadi and Hejazi (2008) and Al Manaseer (2009)). This study uses pooled estimation models, in which the linear functional form is applied to examine the inter-relation between measures of bank profitability performance and the determining factors. Furthermore, the study applies the Ramsey's Reset test to assure that the functional form is not mis-specified

\subsection{Model and Operational Definitions of Variables}

The linear model used to examine the determinants of bank profitability is shown below. Moreover, the proxies used to measure the variables of the study are presented and explained in Table 1.

$$
\boldsymbol{I}_{i j t}=\alpha_{0}+\gamma_{\mathrm{t}} \mathrm{CD}+\alpha_{\mathrm{i}} \mathrm{B}_{\mathrm{ijt}}+\beta_{\mathrm{j}} \mathrm{M}_{\mathrm{jt}}+\delta_{\mathrm{j}} \mathrm{C}_{\mathrm{j}}+\varepsilon_{\mathrm{ijt}}
$$

Where,

$\mathrm{I}_{\mathrm{ijt}}$

$\mathrm{CD}$

$\mathrm{B}_{\mathrm{ijt}}$

$\mathrm{M}_{\mathrm{jt}}$

$\mathrm{C}_{\mathrm{j}}$

$\gamma_{\mathrm{t}}, \alpha_{\mathrm{i}}, \beta_{\mathrm{j}}$ and $\delta_{\mathrm{j}}$

$\alpha_{0}$

$\varepsilon_{\mathrm{ijt}}$
The measure of profitability for bank (i) in country (j) at time ( $t$ ).

Dummy variable $=1$ if there is a cries and $=0$ otherwise.

The column vector of internal variables for bank (i) in country (j) at time (t).

The column vector of external variables for country $(j)$ at time $(t)$.

The column vector of country dummy variables.

Row vectors of slope coefficients of regressors.

The constant.

The error term.

Table 1. The proxies used to measure the variables of the study

\begin{tabular}{|c|c|c|}
\hline Variable & Proxy & Description/Explanation \\
\hline Profitability & $\begin{array}{l}\text { ROAA: Return on average } \\
\text { assets } \\
\text { ROE: Return on average equity }\end{array}$ & $\begin{array}{l}\text { Net income after tax/ average assets } \\
\text { Net income after tax/ average equity }\end{array}$ \\
\hline Liquidity & $\begin{array}{l}\text { NER: Non-interest earning } \\
\text { assets-to-total assets }\end{array}$ & $\begin{array}{l}\text { - None interest earning assets: cash, non-interest earning } \\
\text { deposits and other non-interest assets. }\end{array}$ \\
\hline Risk & $\begin{array}{l}\text { LOR: Total loans-to-total } \\
\text { assets }\end{array}$ & \\
\hline $\begin{array}{l}\text { Off-balance sheet } \\
\text { activities }\end{array}$ & $\begin{array}{l}\text { OBR: Off-balance sheet } \\
\text { activities-to-total assets }\end{array}$ & $\begin{array}{l}\text {-Off-balance sheet activities: non-interest income and fees } \\
\text { acquired from various contingent liabilities such as insurance, } \\
\text { security underwriting, letters of credit, derivatives and other } \\
\text { types of non-conventional banking activities. }\end{array}$ \\
\hline Capital & $\begin{array}{l}\text { EQR: Equity capital-to-total } \\
\text { assets }\end{array}$ & -Equity capital: book value of equity (assets-liabilities) \\
\hline Efficiency & OHR: Overhead-to-total assets & -Overhead: personal and non-interest expenses. \\
\hline Size & $\begin{array}{l}\text { LTA: Natural logarithm of the } \\
\text { bank's total assets }\end{array}$ & \\
\hline $\begin{array}{l}\text { Economic } \\
\text { Condition }\end{array}$ & $\begin{array}{l}\text { GDPGR: Gross domestic } \\
\text { product real growth rate in the } \\
\text { five countries. }\end{array}$ & \\
\hline Inflation & $\begin{array}{l}\text { INF Inflation rate in the five } \\
\text { countries. }\end{array}$ & \\
\hline Dummy Variables & $\begin{array}{l}\text { - CD: Crises dummy variable } \\
\text { - Four dummy variables are } \\
\text { included to account for the } \\
\text { differences between the } \\
\text { countries that may affect the } \\
\text { determinants of banks' } \\
\text { profitability. }\end{array}$ & $\begin{array}{l}-(C D=1 \text { for the years } 2008-2009 \text {, and }=0 \text { for the other years } \\
\left(\text { see footnote }{ }^{2}\right) . \\
\text { - Banks in Saudi Arabia provide the base country }\end{array}$ \\
\hline
\end{tabular}




\subsection{Data and Sample}

Pooled data for 24 Islamic banks operating in Bahrain, Kuwait, Qatar, Saudi Arabia and UAE over the 2005-2012 period is used in the current study. Table 2 shows the distribution of these banks by country. The study employs the pool sample analysis because of the advantages of pooling the sample. It has been argued that the pool sample has many advantages. Pooling data generates more informative data, more variability, less co linearity among variables, more degrees of freedom, and more efficiency (Gujarati, 2004).

Table 2. Distribution of the investigated banks by country

\begin{tabular}{clllllllllc}
\hline & \multicolumn{2}{c}{ Bahrain } & \multicolumn{2}{c}{ Kuwait } & \multicolumn{2}{c}{ Qatar } & \multicolumn{2}{c}{ Saudi Arabia } & \multicolumn{2}{c}{ UAE } \\
\cline { 2 - 13 } & No. & $\%$ & No. & $\%$ & No. & $\%$ & No. & $\%$ & No. & $\%$ \\
\hline Banks & 7 & 29 & 6 & 25 & 3 & 13 & 2 & 8 & 6 & 25 \\
\hline
\end{tabular}

Data is obtained from the Bank scope database. In so far as possible, the Bank scope database converts the data to common international standards to facilitate comparisons. Data related to growth rate of gross domestic product, and inflation is obtained from the International Monetary Fund's Statistics, measured in the year 2005 prices.

Table 3 shows positive economic growth rates in the five countries in the 2005-2012 period, the highest being for Qatar with an average of $13.8 \%$ while UAE have the lowest with an average $3.1 \%$. The five countries have varying inflation experience. Bahrain has the lowest while the ratios for the other four countries are close to each other.

Table 3. Macroeconomic indicators for the five countries in the 2005-2012 period

\begin{tabular}{lllll}
\hline \multirow{2}{*}{ Countries } & \multicolumn{2}{c}{$\begin{array}{c}\text { GDP growth rate \% } \\
\text { (GDPGR) }\end{array}$} & \multicolumn{2}{c}{$\begin{array}{c}\text { Inflation \% } \\
\text { (INF) }\end{array}$} \\
\cline { 2 - 5 } & Mean & S.D & Mean & S.D \\
\hline Bahrain & 5.4 & 2.2 & 2.4 & 1.1 \\
\hline Kuwait & 3.5 & 4.9 & 5.1 & 2.5 \\
\hline Qatar & 13.8 & 4.5 & 5.3 & 7.5 \\
\hline Saudi Arabia & 6.3 & 2.1 & 4.5 & 2.7 \\
\hline UAE & 3.1 & 3.5 & 5.1 & 4.7 \\
\hline
\end{tabular}

Finally, Table 4 contains the average values of some indicators during the 2005-2012 periods for the five countries. In fact, these ratios are the proxies used to measure the variables of the study. This table indicates that the loans constitute more than $50 \%$ of the Islamic banks total assets. Furthermore, the Islamic banks are well capitalized as the equity to total assets ratio is $21 \%$ which is higher than most of the regulations required. On the other hand the off balance sheet to total assets ratio is only $11 \%$ which is very low. This can be attributed to the religious constraints imposed on Islamic banks that prevent them from providing many banking services.

Table 4. Some indicators for the Islamic banks investigated during the 2005-2012 period

\begin{tabular}{lll}
\hline \multirow{1}{*}{ Islamic banking indicators } & \multicolumn{2}{c}{ Islamic banks } \\
\cline { 2 - 3 } & Mean & S.D \\
\hline Return on assets (ROAA) & 0.025 & 5.32 \\
\hline Return on equity (ROAE) & 0.096 & 23.33 \\
\hline Non-earning assets-to-total assets (NER) & 0.10 & 0.09 \\
\hline Loan-to-total assets ratio (LOR) & 0.517 & 0.231 \\
\hline Off-balance sheet-to-total assets (OBR) & 0.113 & 0.112 \\
\hline Equity-to-total assets (EQR) & 0.210 & 0.119 \\
\hline Overhead-to-total assets (OHR) & 0.028 & 0.037 \\
\hline Total assets (TA in millions) & 8835 & 12338 \\
\hline
\end{tabular}




\subsection{Data Analysis and Hypotheses}

To achieve the objectives of the study, pooled regression model was estimated, in which the dependent variable is ROAA. The original model included four dummy variables to capture the effect of the different countries. None of them was found to be statistically significant. Another dummy variable was used for the crises (CD) to capture the impact of the crisis in Islamic banks' profitability (Note 1). In addition, six interaction dummy variables (one for each internal independent variable) were included to examine whether the impact of this crisis vary with variation on each internal determinant of Islamic banks' profitability. Table 5 shows these interaction dummy variables and how they were calculated.

Table 5. Description of the interaction dummy variables

\begin{tabular}{lc}
\hline Interaction Variable & Description/Explanation \\
\hline CDNER & CD X NER \\
\hline CDLOR & CD X LOR \\
\hline CDOBR & CD X OBR \\
\hline CDEQR & CD X EQR \\
\hline CDOHR & CD X OHR \\
\hline CDLTA & CD X LTA \\
\hline
\end{tabular}

The regression analysis performed including all variables but many of them find to be insignificant. A number of restrictions were imposed on the general model. Its validity was tested using the F-deletion test. The process was continued until the final model that best represent the phenomenon under investigation was reached (Note 2). The final model is presented in Table 6 .

Table 6. Summary of the result of the final pooled model (ROA) (Note 3)

\begin{tabular}{ccccc}
\hline $\begin{array}{c}\text { Independent } \\
\text { Variables }\end{array}$ & Coefficients & T value & Sig & VIF \\
\hline (Constant) & $-12.4472 .834-$ & -4.893 & $0.000^{* *}$ & \\
\hline CD & -9.169 & -1.232 & 0.220 & 1.047 \\
\hline GGDP & .334 .067 .307 & 4.994 & $0.000^{* *}$ & 1.114 \\
\hline EQR & 29.392 & 7.861 & $0.000^{* *}$ & 2.068 \\
\hline CDEQR & -27.906 & -5.608 & $-0.000^{* *}$ & 3.937 \\
\hline CDLTA & .658 .000 & 4.317 & $0.000^{* *}$ & 3.537 \\
\hline LTA & .877 & 2.984 & $0.003^{* *}$ & 1.312 \\
\hline CDOHR & 54.064 & 4.212 & $0.000^{* *}$ & 2.337 \\
\hline CDNER & -29.909 & -3.705 & $0.000^{* *}$ & 3.099 \\
\hline $\mathbf{F}$ & & 18.427 & $0.000^{* *}$ & \\
\hline $\mathbf{R}^{2}$ & & 0.437 & & \\
\hline
\end{tabular}

\section{Islamic Banks}

\subsection{Islamic Banks and Financial Crisis}

Islamic bank, simply, is deposit-taking institution, which provides all currently known banking activities, except for borrowing and lending based on interest. On the liabilities side, it mobilizes funds based on Islamic modes of financing such as Mudaraba, Murabaha, and Musharaka (Note 4). Furthermore, it accepts demand deposits from clients, which are treated as interest-free loans and are guaranteed. On the assets side, it advances funds on a profit and loss sharing or debt-creating basis, in accordance with the Shari'ah (Islamic law). Also, it plays the role of an 
investment manager for the owners of time deposits, usually called investment deposits. In addition, equity holding as well as commodity and asset trading constitute an integral part of Islamic banking operations.

In summary, an Islamic bank is a bank that operates in accordance with Shari'ah and is guided by Islamic economics. In particular, Islamic law prohibits the collection and payment of usury (interest) on the bank's loans and deposits. In addition, it prohibits Islamic banks from using or dealing in certain commodities and activities such as pork, alcoholic liquor, gambling and dealing in derivatives. The depositors also share in the profits of the bank according to a predetermined ratio. This is unlike a conventional bank which borrows funds paying interest on one side of the profit and loss account, and lends funds, charging interest, on the other side (Iqbaland Molyneux, 2005).

Cihakand Hesse, (2010) argue that the profit sharing mechanisms allow Islamic banks to maintain their net worth and avoid the deterioration of their balance sheets under difficult economic situations. Therefore, Islamic banks remain stable at the early phases of the crisis for four main reasons. First, prohibition of Riba and Gharar restricted Islamic banks from dealing with some instruments which considered main contributors of financial crisis such as Collateralized Debt Obligation, cash management bill and credit default swap. Second, Islamic bank's financing activities are more focused on the real economic activities such, as Murabaha, Ijarah and Istinsa. According to the Council of Islamic Banks and Financial Institutions, for the Islamic banks in the GCC for year 2007, Murabaha comprised of $65 \%$, Ijarah 13\% and Istinsa 3\%. Both Murabaha and Ijrah transactions require the Islamic bank to know the client's purpose and use of finance as well the ownership of the asset by the bank. Although Musharakah and Mudharabah both provide better risk sharing while keeping strong link to the real estate sector, they are used minimally for different reasons. This help in ensuring that the funds are used for their stated purposes. Third, the lack of interbank market to Islamic banks and the absence of Lender of last resort facility resulted in excess liquidity requirement which prevent Islamic banks from serious impacts of these crises. Finally, unavailability of hedging instruments for Islamic financial institutions, which was perceived as weakness before the crisis, became a strengthening factor for them.

On the other hand, the financial crisis impacted Islamic banks indirectly. The financial crisis has generated a chain reaction whereby the slowdown in the real economies of the developed countries has started to affect economic growth and investment activities in export driven economies of the developing countries through lower trade in goods and services as well as through the declining commodity prices including oil.

\subsection{The Determinants of Banks' Profitability}

The determinants of banks' profitability are divided into two main categories: The first category is called internal determinants and the second the external determinants. The internal determinants represent the factors that are controllable by management. It shows the differences across banks in management policies and decisions relating to sources and uses of funds, capital, liquidity, and expenses. The internal determinants of bank' profitability that are most commonly cited in the literature include liquidity ratios, bank risk, capital ratios, operating costs, and bank size (see Bourke (1989); Demirguc-Kunt and Huizinga (1999); Ben-naceur and Goaied (2008); Khrawish, Al-Abadi and Hejazi (2008) and Al Manaseer (2009)). The crises-related determinant is concerned with the impact of the financial crises on Islamic banking profitability. All these determinants are discussed in the following subsections.

Crisis

The economic decline generated by financial crisis affected the investment and financing activities of financial institutions including those of Islamic banks. Furthermore, it reduced the funding of these banks through lower personal savings and declining corporate profits. Similarly, decline in the real-estate markets where these banks have large direct and indirect exposures is also another source of risk. Finally, Islamic banks in some regions may face risk on their financing and investment side of the balance sheet due to the crisis induced volatility of equity markets where these banks have large positions. The relative importance of each of these factors varies by the region. For example, the banks in the GCC are more exposed to real estate market risk, followed by risk of international equity markets. Empirically, Dietrich and Wanzenried, (2011) examined factors that affect the profitability of Swiss banks over the period from 1999 to 2009 by using the pre-crisis period of 1999-2006 and the crisis years of 2007-2009. Their results provide evidence that the financial crisis did have a significant impact on banks profitability. All the above suggest that the financial crisis affects the Islamic banks profitability negatively therefore the following hypothesis is proposed:

\section{H1: There is a negative relationship between financial crisis and banks' profitability.}

The main concern of this study is to examine the impact of financial crisis in GGC Islamic banking profitability. To examine this impact it is important to include other variables that found in the literature to have impact on banks' 
profitability and to examine the interactions of each internal variable with this crisis to see whether the impact of this crisis vary with variation on each internal determinant of Islamic banks' profitability separately across the GCC countries.

\subsection{The Internal Determinants}

Liquidity

The trade-off between liquidity and profitability may be regarded as the main problem in managing the bank's funds. Bank managers feel pressure from stockholders for more profits, which may be earned by investing in long-term securities. This could lead to reducing the idle cash balance. On the other hand, managers are acutely aware that these actions greatly reduce liquidity, which is needed to meet credit demands of long-standing deposits withdrawals. Goddard, et al., (2004) argue that holding a relatively high proportion of liquid assets reduces both the bank's profitability and risk. Liquidity holding represents an expense to the banks because it reduces the amount of money available for investment, which results in low profitability. These arguments suggest that high liquidity seems to reduce banks' profitability. Thus, the following hypothesis is proposed:

\section{H2: There is a negative relationship between liquidity and banks' profitability.}

On the other hand, Banks those hold more marketable securities relative to total assets than would otherwise be deemed necessary before the crisis bear a high opportunity cost by not investing those funds in loans yielding much higher returns. However, maintaining relatively large amounts of liquid assets provides additional liquidity for banks during the crisis when alternative investment opportunities are scarce and when banks continue to need quick access to liquid, inexpensive, and easily accessible sources of funds to cover their losses. Thus, we hypothesize that the bank's vulnerability during the financial crisis is inversely related to the amount of short term assets held by the bank. Therefore, the following hypothesis is proposed

\section{H3: The impact of bank crisis on its profitability will decrease as the liquidity of the bank increases}

Risk

Risk is defined as something, which exists on the range between certainty and complete uncertainty (Gardener, 1986). Credit risk occurs when promised cash flows, that is, the principal and interest rates on the primary assets (loans) held by banks, are not paid in full on their maturity date. Banks are intermediaries between lenders and borrowers. Bank loans are the main interest-earning assets. This implies that the more deposits are transformed into loans, the higher the interest margin and hence, the profits to the bank. In general, bank's loans are more profitable than other investment, but they are more risky. Investors dislike risky outcomes. However, they are willing to hold risky assets where risky assets have present values in excess of those available from non-risky assets. Many empirical studies find that banks loans have positive impact on bank's profitability (see Demirguc-Kunt and Huizinga (1999); Ben-naceur and Goaied (2008)). Based on this the following hypothesis is proposed:

\section{H4: There is a positive relationship between risk and banks' profitability.}

The financial crisis was largely attributed to liberal lending guidelines applied to mortgages. Madura, Martin, and Taylor (1994) find that the amount of real estate loans is positively related to ex ante risk. Blasko and Sinkey (2006) notice that real estate banks are riskier since they tend to be more capital constrained and they keep higher ratios of fixed-rate loans to total assets. Furthermore, Cole and White (2012) conclude that the basic drivers of bank financial performance and failure during the financial crisis are concentrations of commercial real estate loans.

Thus, we hypothesize that the bank's sensitivity to the financial crisis is positively related to the proportion of loans held by the bank. On the other hand, banks that maintain a relatively large proportion of risky loans are more susceptible to financial losses during the crisis than banks with lower proportion of risky assets. Based on this the following hypothesis is proposed

\section{H5: The impact of financial crisis on banks' profitability increased with level of risk the bank takes}

\section{Off-balance sheet activities}

Banks do not just take loans and offer deposits; they typically offer a range of financial services to customers, including unit trusts, stock broking facilities, insurance, pension funds, and assets management. Heffernan (2001) provides two reasons why banks engage in non-conventional activities. First, a bank provides intermediary services to its borrowers and depositors, thereby reducing the financing costs for these customers. If a bundle of services is demanded by the customer, then banks may be able to develop a competitive advantage, and profit from offering these services. Second, buying a basket of financial services from banks helps customers to overcome information 
asymmetries, which can make it difficult to judge quality. Furthermore, by offering a wider range of services, the risk of lending is spread across a large number of asset categories (Diamond, 1984). Based on the previous argument the following hypothesis is proposed:

\section{H6: There is a positive relationship between off balance sheet activities and banks' profitability.}

Banks that generate a greater proportion of non-interest income may be less susceptible to the financial crisis because this type of income should not be disrupted as much as income from lending operations. Rogers and Sinkey (1999) find that bank which are more heavily involved in nontraditional activities and thus generate more fee income reduce their risk exposure to a higher degree than bank that engage mostly in traditional activities. Also, banks that diversify their earnings stream thorough increased fee income may lower the volatility and uncertainly of their income during the crisis, especially if fee income and interest income are uncorrelated. This argument suggests the development of the following hypothesis:

\section{H7: The impact of banks' crises in their profitability will decrease as their off-balance sheet activities increased}

\section{Equity}

According to conventional wisdom in banking, a higher equity-to-total assets ratio is associated with a lower after-tax profit. The arguments in favour of this hypothesized negative relationship between equity and earning can be explained by the following: a higher equity ratio tends to reduce the risk on equity and therefore lower the equilibrium expected return on equity required by investors. Furthermore, a higher equity ratio lowers after-tax earnings by reducing the tax shield provided by the deductibility of interest payments.

Despite these arguments, Most of the studies on banks profitability find a positive relationship between the equity asset ratio and bank net interest margin (see for example: Berger (1995b); Demirguc-Kunt and Huizinga (1999); Ben-naceur and Goaied (2008); Khrawish, Al-Abadi and Hejazi (2008)). Berger (1995b) proposes several theoretical explanations for the positive association between the equity asset ratio and bank profitability. For example, expected bankruptcy costs may be relatively high for a bank maintaining equity asset ratio below its equilibrium value. A subsequent increase in the equity asset ratio should lead to an increase in bank's net interest margin by lowering insurance expenses on uninsured debt. Furthermore, the higher equity-to-asset ratio, the lower the need for external funding and therefore higher net interest margin. This supports the view that profitable banks remain well capitalized; or the view that well capitalized banks enjoy access to cheaper sources of funds. Based on this explanation, the following hypothesis is proposed:

\section{H8: There is a positive relationship between equity and banks' profitability.}

Banks can withstand a crisis if they hold a higher level of capital (Acharya, Mehran, and Thakor 2010). Holding asset quality constant, a bank with less capital in proportion to assets is more likely to fail during the financial crisis, because it has less of a cushion to absorb future losses. Thus, a bank's exposure to the financial crisis may be inversely related to its level of capital, as a bank that has relatively low capital may be punished by the market to a greater degree during the financial crisis. Based on this argument, the following hypothesis is proposed:

\section{H9: The impact of financial crisis on banks' profitability decreased with increasing bank's capital}

\section{Efficiency}

Resti (1996) argues that bank efficiency represents a social optimal target since it reduces the cost of financial intermediation which drives down the drainage of real resources through transferring funds efficiently from savers to producers. As a result, regulatory authorities are interested in fostering more efficient operating practices that result in a market equilibrium to promote the maximum productive efficiency. Furthermore, the economic theory of the firms assumes that production should take place in an environment where managers aim to maximize profits by operating in the most efficient manner. According to the competitive model, firms which fail to do so, will be driven from the market by ones that are more efficient. Bourke (1989), Guru, Staunton and Balashanmugam (2002) and Athanasoglou, Brissimis and Delis (2005) revealed that efficient expenses management was one of the most significant variables in explaining high bank profitability based on that, the following hypothesis is developed.

\section{H10: There is a positive relationship between efficiency and banks' profitability.}

Banks can withstand a crisis if they operating in the most efficient manner since it reduce the cost of financial intermediation through transferring funds efficiently from savers to producers (Berger and Bouwman, 2013). This is considerably important during the financial crises because they have less profit to absorb future losses. Banks which fail to operate efficiently during the financial crises will be driven from the market very quickly. Based on this the following hypothesis is proposed: 


\section{H11: The impact of financial crisis on banks' profitability decreased with increasing bank's efficiency}

Size

Scale efficiencies can increase profits as the unit cost of production falls with increased size. More precisely, it can improve profitability by reducing costs per unit of output for a given set of output quantities and input prices. Furthermore, it may increase profits through improvements in profit efficiency that involves superior combinations of inputs and outputs resulting from larger size. Finally, it may improve profits through the exercise of additional market power in setting prices (Molyneux and Iqbal, 2005). The above arguments suggest that economies of scale enhance banks' profitability. Thus, the following hypothesis is proposed:

\section{H12: There is a positive relationship between Size and banks' profitability.}

Uzun and Webb (2007) find that bank size is positively related to the degree of securitization. They may be considered to be too big to fail. In addition, they may be more diversified across financial services, which could reduce the potential problems during a banking crisis. Large size is more important for profitability in Islamic banks to ensure long-term survival. This is because Islamic banks are unable to use 'lender of last resort' function of central banks as this involves interest payments. Therefore, the following hypothesis is proposed:

\section{H13: The negative impact of bank crisis on their profitability decreased as the bank size increased}

\subsection{The External Determinants}

In addition, to the internal factors, the banks' profitability can also be affected by external factors. The external determinants represent the factors that are beyond the control of the bank's management. These include economic conditions and inflation (Smirlock (1985); Demirguc-Kunt and Huizinga (1999); Ben-naceur and Goaied (2008); Ben Naceur and Omran, 2011) Khrawish, Al-Abadi and Hejazi (2008)).

\section{Economic conditions (business cycle)}

The association between economic conditions and the financial sector performance is well documented in the literature (Demirguc-Kunt and Maksimovic, 1996). During cyclical downswings, lending activities usually decrease. This is due to the fact that such periods are normally associated with increased risk. Similarly, provisions held by banks will be higher due to the deterioration of the quality of loans. On the other hand, the demand for credit and stock market transactions would be strengthened substantially during favourable economic conditions. The interest margin may widen. Thus, revenues grow faster than costs leading to increased profits. Furthermore, investment growth may increase the banks' off-balance sheet activities which may increase their profitability, while the opposite may hold true during economic slowdowns (Athanasolou, Brissims and Delis, 2005). The above argument leads to the following hypothesis:

\section{H14: There is a positive relationship between favourable economic conditions and banks' profitability.}

\section{Inflation}

Inflation is defined as a sustained general rise in prices in an economy. Revel (1980) introduces the issue of the relationship between bank profitability and inflation. He argues that the effect of inflation on bank profitability depends on the assumption that banks' wages and their other operating expenses increase at a faster rate than inflation. The question is how mature the economy is so that future inflation can be accurately forecasted and thus banks can accordingly manage their operating costs.

The extent to which inflation affects bank profitability depends on whether inflation is anticipated or unanticipated. A fully anticipated inflation rate by the banks' management means that banks can appropriately adjust interest rates in order to increase their revenues faster than their costs and thus acquire higher economic profits. However, if banks are sluggish in adjusting their interest rates, costs may increase faster than revenues and thus affect profits negatively. In addition, banks would benefit from inflation if they had demand deposits on which they pay zero interest, provided that customers are slow in switching into interest-bearing deposits (Bashir, 2000). On the other hand, unanticipated inflation could lead to improper adjustment of interest rates and hence to the possibility that costs could increase faster than revenues. Overall, considering the fact that banks are more able to anticipate inflation than customer, the above argument suggests that inflation seems to enhance banks' profitability. Hence, the following hypothesis is proposed:

H15: There is a positive relationship between inflation and banks' profitability. 


\section{Analyzing and Discussing the Study}

\subsection{Results of Study}

As illustrated in Table (6), the final model has $\mathrm{R}^{2}$ of 0.437 . This means that the model explains almost $44 \%$ of the variation in the banks' profitability measured by ROAA. The high probability of the F statistic $(0.000)$ indicates that the independent variables are jointly significant in explaining the variation in the banks' profitability. Furthermore, the VIF for the variables investigated ranged between 1.114 and 3.937. All are far below the accepted level (10) suggested by Gujarati (2004). This indicates that multicollinearity is not problematic in the current study. The results of the Ramsey's Reset test performed show that there is no evidence that the model is mis-specified (see footnote 3).

1- As expected the financial crisis CD variable is found to have a negative impact on Islamic banks' profitability although its impact is statistically insignificant which does not give support to $\mathrm{H}_{1}$. This may attributed to the prohibition of Riba and Gharar which restricted Islamic banks from dealing with some instruments which considered main contributors of financial crisis such as Collateralized Debt Obligation and credit default swap. In addition, Islamic bank's financing activities are more focused on the real economic activities such, as Murabaha, Ijarah and Istinsa that requires the Islamic bank to know the client's purpose and use of finance as well the ownership of the asset by the bank. This help in ensuring that the funds are used for their stated purposes. Finally, unavailability of hedging instruments for Islamic financial institutions prevents them from the bad consequences of the financial crisis.

2- The GGDP is positively related to banks' ROAA and its impact is statistically significant. The positive impact of GGDP in banks' profitability provides support to the argument of association between economic growth and financial sector performance. These findings support $\mathrm{H}_{14}$. This is in line with similar studies that have focused on banks' profitability e.g. Tanna, Kosmidou, and Pasiouras (2005); Hassan and Bashir (2003). Concerning the impact of size on banks' profitability, the study reveals that LTA has appositive and statistically significant impact on banks' profitability. This may indicates that Islamic banks are benefiting from large size through improvements in profit efficiency that involves superior combinations of inputs and outputs resulting from larger size, which is consistent with $\mathrm{H}_{12}$. Furthermore, EQR has a positive and statistically significant impact on ROAA, which supports $\mathrm{H}_{8}$. This may indicate that increasing equity decreases the bankruptcy costs, and results in higher return on assets. Similar result is reported by Berger (1995b); Demergue-Kunt and Huizinga (1999). On the other hand, CDEQR has a negative and statically negative impact on ROAA, which support $\mathrm{H}_{9}$. This may explains the insignificant impact of financial crisis in Islamic banks' profitability as they hold a higher level of capital.

3- The impact of interaction of the overhead with financial crisis (CDOHR) is positive and statically significant which is in line with $\mathrm{H}_{11}$. This means that the impact of the financial crisis on banks' profitability increases with the increase in overhead expenses which may imply that Islamic banks are operating in the most efficient manner since it reduce the cost of financial intermediation through transferring funds efficiently from savers to producers. Furthermore, CDLTA variable has a positive and statistically significant impact on banks' profitability, which is against $\mathrm{H}_{13}$. This means that the impact of the crisis on Islamic banks' profitability increases as the size of the bank increases. This may attributed to the fact that larger banks have more investments on countries which affected more by the financial crisis while most of the investments for smaller banks are locally

4- In contrast the impact of the interaction of none interest earning assets with financial crisis (CDNER) is negative and statically significant which is against $\mathrm{H}_{3}$. This may attributed to the fact that Islamic banks hold more liquidity than would otherwise be deemed necessary before the crisis and when the crisis started they increase their liquidity which resulted in decreasing their profitability. Finally, OBR, LOR and INF and their interactions with financial crisis are all have statistically insignificant impact on Islamic banks' profitability. The insignificant impact of OBR on Islamic banks profitability can be attributed to the religious constraints imposed on Islamic banks that prevent them from providing many banking services.

\section{Conclusion}

This study investigated the impact of the financial crisis on the determinants of Islamic banks' profitability in GCC countries over the 2005-2012 period. The study employed several internal and external factors that affect banks' profitability. The study finds that:

1) The financial crisis does not have significant impact on Islamic banks profitability.

2) Favorable macro-economic conditions enhanced Islamic banks profitability. Moreover, both bank size and equity capital are important factors in increasing Islamic banks' profitability. Furthermore Increasing owners' equity decreased the impact of financial crisis on Islamic banks profitability. 
3) The impact of the financial crisis on Islamic banks' profitability increase with increasing banks total assets and overhead expenses.

4) Finally, the study finds that the impact of the crisis on Islamic banks profitability increased with increasing liquidity.

\section{Recommendations}

1) Increase both Islamic banks' size and equity capital in order to increase their profitability and decrease the impact of financial crisis in their performances.

2) Improve Islamic banks efficiency throw reducing their overhead expenses in order to increase their profitability.

3) Decrease Islamic banks liquidity throw investing this liquidity in more profitable investments

4) Searching for Islamic finance tools and investment methods which comply with Islamic sharia and cope with financial developments in this changing environment.

However, the reader should bear in mind that the study covered the period from2005-2012. Furthermore, the sample size is confined to five countries. It might be interesting to carry out the same research over a larger number of countries that have Islamic banks. Moreover, it could be important to examine other non-financial measures for Islamic banks' performance.

\section{References}

A. Dietrich, \& G. Wanzenried. (2011). Determinants of bank profitability before and during the crisis: Evidence from Switzerland. Journal of International Financial Markets, Institutions and Money. http://dx.doi.org/10.1016/j.intfin.2010.11.002

Abdin, Adnan Hamdi. (2008). Financial Fraud: Reasons, Methods of Discovery, and Prevention Means $\left(1^{\text {st }}\right.$ ed.). Beirut, Lebanon: Library of Lebanon Publishers.

Acharya, Viral V., Hamid Mehran, \& Anjan V. Thakor. (2010). Caught between Scylla and Charybdis? Regulatingbank leverage when there is rent seeking and risk shifting. Working paper.

Al Manaseer, M. F. (2009). Bank Profitability Islamic and Traditional Banks. Saarbrucken, Germany: VDM Verlag Dr. Muller Aktiengesellschaft\& KG.

Anayiotos, GH, Toroyan, \& Vamvakidis, A. (2010). The efficiency of emerging europe'sbanking sector before and after the recent economic crisis. Financial Theory and Practice, 34(3), 247-267.

Athanasoglou, P., Brissimis, S., \& Delis, M. (2005). Bank-specific, industry-specific and acroeconomic determinants $\begin{array}{llllll}\text { of bank profitability. } & \text { Retrieved } & 8 & \text { February } & \text { 2012, } & \text { from }\end{array}$ http://www.hfaa.gr/Docs/8/ATHANASOGLOU-BRISSIMIS-DELIS.pdf

Bank for International Settlements. (2012). 82th Annual Report, June, Basel.

Bashir, A. (2000). Determinants of profitability and rate of return margins in Islamic banks: some evidence from the Middle East. Paper presented at the Economic Research Forum $7^{\text {th }}$ annual conference, Amman- Jordan, 26-29, October.

Ben, N., S., \& Omran, M. (2011). The effects of bank regulations, competition, and financial reforms on banks' performance. Emerging Markets Review, 12, 1-20. http://dx.doi.org/10.1016/j.ememar.2010.08.002

Ben-Naceur, S. (2003). Thedeterminants of the Tunisian banking industry profitability: panel evidence. Paper presented at the Economic Research Forum $7^{\text {th }}$ annual conference, Marrakesh-Morocco, 16-18 December.

Ben-Naceur, S., \& goaied, M. (2008). The Determinants of Commercial Bank Interest Margin andProfitability: Evidence from Tunisia. Frontiers in Finance and Economics, 5(1).

Berger, A. (1995b). The relationship between capital and earnings on banking. Journal of Money, Credit \& Banking, 27(2), 432-456. http://dx.doi.org/10.2307/2077877

Berger, Allen N., \& Christa H.S. Bouwman. (2013). How does capital affect bank performance during financial crises?, Journal of Financial Economics, 109, 146-176. http://dx.doi.org/10.1016/j.jfineco.2013.02.008

Blasko, M., \& Sinkey, Jr. J. F. (2006). Bank asset structure, real-estate lending, and risk taking. The Quarterly Review of Economics and Finance, 46(1), 53-81. http://dx.doi.org/10.1016/j.qref.2004.11.002 
Bourke, P. (1989). Concentration and other determinants of bank profitability in Europe, North America and Australia. Journal of Banking and Finance, 13(1), 65-79. http://dx.doi.org/10.1016/0378-4266(89)90020-4

Cihak, M., \&Hesse, H. (2010). Islamic banks and financial stability: An empirical analysis. Journal of Financial Services Research, 38(2), 95-113 (Springer, December). http://dx.doi.org/10.1007/s10693-010-0089-0

Cole, R.A., \& White, L.J. (2012). Déjà vu All Over Again: The causes of U.S. commercial bank failures this time around. J. Finan. Services Res, 42(1), 5-29. http://dx.doi.org/10.1007/s10693-011-0116-9

Demirguc-kunt, A., \& Huizinga, H. (1999). Determinants of commercial bank interest margins and profitability: some international evidence. World Bank Economic Review, 13(2), 379-408. http://dx.doi.org/10.1093/wber/13.2.379

Demirguc-kunt, A., \& Maksimovic V. (1996). Stock market development and financing choices of firms. World Bank Economic Review, 10(2), 341-369. http://dx.doi.org/10.1093/wber/10.2.341

Diamond, D. (1984). Financial intermediation and delegated monitoring. Review of Economic Studies, 51(3), 393-414. http://dx.doi.org/10.2307/2297430

Ellaboudy, S. (2010). The Global Financial Crisis: Economic Impact on GCC Countries and Policy Implications. International Research Journal of Finance and Economics, 41, 177-190.

Gardner, E. (1986). UK banking supervision: evolution, practice and issues. G. Allen and Unwin, Boston.

Goddard, J., Molyneux, P., \& Wilson J. (2004). The profitability of European banks: a cross-sectional and dynamic panel analysis. The Manchester School, 72(3), 363-381. http://dx.doi.org/10.1111/j.1467-9957.2004.00397.x

Gujarati, D.N. (2004). Basic econometrics. McGraw-Hill, London.

Guru, B., Staunton, J., \& Balashanmugam, A. (2002). Determinants of Commercial Bank Profitability in Malaysia. University Multimedia Working Papers.

Hassan, M., \& Bashir, A. (2003). Determinants of Islamic Banking Profitability. Paper presented at the international seminar on Islamic wealth creation organized by Islamic Development Bank and Centre for Middle Eastern and Islamic Studies, UK, 7-9 July, 2003.

Heffernan, S. (2001). Modern Banking in Theory and Practice. John Wiley and Sons Ltd., Chichester.

Holden, K., \& El-Banny, M. (2004). Investment in information technology system and other determinants of bank profitability in the UK. Applied Financial Economics, 14(5), 361-365. http://dx.doi.org/10.1080/0960310042000211623

Iqbal, M., \& Molyneux, P. (2005). Thirty years of Islamic banking: history, performance, and prospects. Palgrave Macmillan, Great Britain.

Kassim, S., \& Majid, M. S. A. (2010). Impact of financial shocks on Islamic banks: Malaysian evidence during 1997and 2007 financial crises. International Journal of Islamic and Middle Eastern Finance and Management, 3(4), 291-305. http://dx.doi.org/10.1108/17538391011093243

Messier Jr., William, Simon, Chad, \& Smith, Jason. (2011, February). Two Decades of Behavioral Research on Analytical Procedures: What Have We Learned? Auditing: A Journal of Practice \& Theory.

Molyneux, P., \& Iqbal, M. (2005). Banking and financial systems in the Arab world. Palgrave Macmillan, Basingstoke.

Nasar, Magedy, \& Borhamy, Mariam. (2008). The Importance of Using the Analytical Procedures in Auditing Phases Conducted by Department Auditor and Estimating their Reliability according to General Auditing Guidelines, not published research.

Perlich, H. (2009). The impact of the GFC on Australia as a Dual economy. Journal ofAustralian Political Economy, (64), 65-90.

Resti, A. (1996). Cone-Rtio DEA with a set of value-based rules: theoretical framework and empirical findings on Italian banks. Research paper [16/96], the University of Wales-Bangor.

Revell, J. (1980). Costs and margins in banking: An international survey. OECD, Paris.

Rogers, K., \& Sinkey, J.F.Jr. (1999). An analysis of nontraditional activities at U.S. commercial banks. Review of Financial Economics, 8, 25-39. http://dx.doi.org/10.1016/S1058-3300(99)00005-1 
Sediry, PhD. Fahda, \& Alonqry, Dr. Hosam. Gap between Expectations Related to Factors of Fulfilling Beneficiaries ' Requirements and the Impact on Organizing and Practicing Auditing in Kingdom of Saudi Arabia and the Contemporary challenges. King Abdul-Aziz University. Saudi Arabia.

Smirlock, M. (1985). Evidence on the (none) relationship between concentration and profitability in banking. Journal of Money, Credit and Banking, 17(1), 69-83. http://dx.doi.org/10.2307/1992507

Smolo, E., \& Mirakhor, A. (2010). The Global Financial Crisis and Its Implications for the Islamic Financial Industry. International Journal of Islamic and Middle Easterb Finance, 3(4), 372-385. http://dx.doi.org/10.1108/17538391011093306

Steven M.G. et al. (2001). Analytical Procedures and Audit Planning Decision. Journal of Accountancy, 191(2).

Sufian, F. (2010). The impact of Asian financial crisis on Bank efficiency: the 1997 experienceof Malaysia and Thailand. Journal of International Development, 22(7), 866-889. http://dx.doi.org/10.1002/jid.1589

Tanna, S., Kosmidou, K., \& Pasiouras, F. (2005). Determinants of profitability of domestic UK commercial banks: panel evidence from the period 1995-2002. Paper presented at the 45 Money Macro and Finance (MMF) Research Group conference organised by Money Macro and Finance Research Group.

\section{Notes}

Note 1. BIS (2012) identify acute-crisis as July 2007 to March 2009. Since quarterly data are not available, we consider 2008-2009 as the periods

Note 2. Applying Ramsey's Reset test to the Model provides $F=0.520$. The calculated F does not exceed the critical $\mathrm{F}$ at $5 \%$ level of significance (for $(2,173)$ the critical $\mathrm{F}$ value is 3.04 at $5 \%$ level of significance).

Note $3 .{ }^{ \pm}$The results are corrected for heteroskedasticity. ${ }^{*}$, and ${ }^{* *}$ indicate significance levels of $5 \%$, and $1 \%$ respectively

Note 4. Mudaraba (Trustee finance contract): provides the entire capital needed to finance a project while the entrepreneur offers his labor and expertise. Profits are shared between them at a certain fixed ratio, whereas financial losses are exclusively borne by the capital's owner. The liability of the entrepreneur is limited only to his time and effort. Murabaha (Mark-up financing): The seller informs the buyer of his cost of acquiring or producing a specified product. The profit margin is then negotiated between them. The total cost is usually paid in installments. Musharaka (Equity participation): The bank enters into an equity partnership agreement with one or more partners to jointly finance an investment project. Profits are shared between them according to the agreed proportion, which may be different from the proportions of capital contributed but, in case of losses, the customer and the bank have to borne these losses according to their capital contributions. 